\title{
ANALISIS PENGARUH FUNDAMENTAL EKONOMI MAKRO DAN SENTIMEN GLOBAL TERHADAP PERKEMBANGAN CREDIT DEFAULT SWAP DI INDONESIA
}

\author{
Riwi Sumantyo \\ riwi_s@yahoo.com \\ Sutanto \\ Fakultas Ekonomi dan Bisnis, Universitas Sebelas Maret Surakarta
}

\begin{abstract}
This study discusses how large the influence of macroeconomic fundamentals consist of inflation, interest rates, composite index (IHSG) and global sentiment side consisting of Fed Fund Rate (FFR), world oil price, and Dow Jones Industrial Average (DJIA) against the investor's perception of investment risk in Indonesia, as measured by the value of Credit Default Swap (CDS) index. This research is a type of quantitative study in which data is used using a numerical scale (number). The data used is a time-series data with periods in this study is January 2008December 2017. The types of data used in this study are secondary data consisting of inflation, foreign debt, IHSG, Fed Fund Rate (FFR), oil price, and Dow JonesIndustrial Average (DJIA), Credit Default Swap. The analysis tool used in this study is Error Correction Model-Eagle Granger (ECM-EG) with Eviews 9 application. The result of this study shows in short term only the variable IHSG and the Dow Jones Industrial Average (DJIA) index significantly affect the value of the CDS index. In the long run only interest rates variable that have no significant effect while other independent variables have significant effect on the CDS index value.
\end{abstract}

Key words: credit default swap (CDS), macroeconomic fundamentals, global sentiment, ECM-EG

\begin{abstract}
ABSTRAK
Penelitian ini membahas seberapa besar pengaruh sisi fundamental ekonomi makro yang terdiri dari inflasi, suku bunga, Indeks Harga Saham Gabungan (IHSG) serta sisi sentimen global yang terdiri dari Fed Fund Rate (FFR), Harga Minyak Dunia, dan indeks Dow Jones (DJIA) terhadap persepsi investor terhadap risiko investasi di Indonesia, yang diukur dengan nilai indeks Credit Default Swap (CDS). Penelitian ini merupakan jenis penelitian kuantitatif dimana data yang digunakan menggunakan suatu skala numerik (angka). Data yang digunakan merupakan data time series dengan periode dalam penelitian ini adalah Januari 2008-Desember 2017. Jenis data yang digunakan dalam penelitian ini adalah data sekunder yang terdiri dari data inflasi, utang luar negeri, IHSG, Fed Fund Rate (FFR), Harga minyak, dan indeks Dow Jones, Credit DefaultSwap. Alat analisis yang digunakan dalam penelitian ini adalah Error Correction Model-Eagle Granger (ECM-EG) dengan aplikasi Eviews 9. Hasil penelitian ini menunjukkan dalam jangka pendek hanya variabel IHSG dan indeks Dow Jones yang berpengaruh signifikan terhadap nilai indeks CDS. Dalam jangka panjang hanya variabel suku bunga yang tidak berpengaruh signifikan sedangkan variabel bebas lain berpengaruh signifikan terhadap nilai indeks CDS.
\end{abstract}

Kata kunci: credit default swap (CDS), fundamental ekonomi makro, sentimen global, ECM-EG

\section{PENDAHULUAN}

Perbaikan dan pembangunan infrastruktur menjadi bagian dari fokus pemerintah saat ini. Dalam melakukan pembangunan, pemerintah membutuhkan dana untuk membiayai proyek tersebut. Salah satu sumber dalam pembiayaan proyek pembangunan adalah utang baik domestik maupun luar negeri. Pendapatan utang Indonesia berasal dari penerbitan obligasi baik negara maupun korporasi dari BUMN atau BUMD, World Bank, Asian Development 
Bank (ADB), Islamic Development Bank (IDB) maupun kerjasama bilateral dengan berbagai negara. Akan tetapi, pendapatan utang yang berlebih tanpa diiringi dengan pen dapatan negara yang cukup dapat menjadi beban utang yang mengalir ke periodeperiode selanjutnya. Sehingga, pemerintah memberlakukan pembatasan utang yang diukur dengan tingkat rasio utang terhadap Pendapatan Domestik Bruto (PDB). Jika tidak, beban utang negara yang membengkak dapat berdampak pada peningkatan potensi risiko ketidakmampuan negara dalam membayar utang (sovereign risk) (Tampubolon dan Hidayat, 2013).

Peringkat kredit dapat digunakan sebagai alat ukur tingkat potensi risiko default di suatu Negara. Menurut Diantimala (2008), risiko default adalah Risiko yang dihadapi oleh investor atau pemegang obligasi dikarenakan pihak penerbit obligasi tersebut gagal bayar atau tidak dapat membayar saat jatuh tempo. Pihak yang mengukur baik risiko bond default atau credit risk adalah institusi global diantaranya; Standard dan Poor Corporation (S and P), Moody"s Investor Services, dan Fitch Investors Services.

Pada tahun 2008 terjadi krisis global yang disebabkan oleh permasalahan pembayaran kredit perumahan yang terkenal dengan sebutan "subprime mortgage default" di Amerika serikat. Krisis ekonomi AS terjadi karena adanya peningkatan konsumsi yang terlalu tinggi di luar batas kemampuan pen dapatan yang dimiliki oleh masyarakat. Hal ini ditandai dengan bangkrutnya sejumlah perusahaan lembaga keuangan internasional yang memiliki reputasi tidak diragukan seperti Lehman Brothers, AIG, Fannie Mae, Freddie Mac pada tahun 2008 (Sugema, 2012).

Pada saat krisis global 2008 tersebut, credit ratings menunjukkan kelemahan dalam pengukuran penilaian potensi risiko dimana selama krisis tersebut credit ratings relatif tidak berubah, hal tersebut menjadi pertanyaan, kenapa dengan penilaian peringkat misalnya " $\mathrm{A}$ " tetapi tiba-tiba lembaga keuangan tersebut bangkrut. Kegaga- lan credit ratings dalam melakukan pengukuran saat subprime mortgage tersebut membuat investor mencari instrumen lain yang dapat memprediksi potensi risiko yang lebih akurat. Hal tersebut memunculkan adanya Credit Default Swap (CDS). Credit Default Swap (CDS) memungkinakan para investor memastikam resiko kredit default pada entitas. Sebagai contoh entitas disini adalah penerbitan obligasi. (Baum dan Wan, 2010). Selain itu Credit Default Swap (CDS) juga dapat digunakan untuk melihat resiko kredit yang banyak terjadi di pasar perdagangan. (Ismailescu dan Kazemi, 2010)

Karlson dan Willebrand (2009) semenjak adanya krisis global banyak bank yang mengalami gagal bayar sehingga bank-bank tersebut juga perlu menerapkan adanya Credit Default Swap (CDS). Credit Default Swap (CDS) menurut Pratomo dan Puspitasari (2008) merupakan instrument derivative kredit yang berfungsi sebagai hedging spekulasi untuk mendapat keuntungan. Credit Default Swap (CDS) merupakan kontrak antara penjual dan pembeli CDS dengan membayar biaya (fixed premium) pada periode tertentu (maturity) dan kompensasi tertentu apabila terjadi credit event, dengan kata lain CDS adalah sejenis perlindungan atau proteksi atas potensi terjadinya risiko kredit atau gagal bayar (credit event). Credit event diartikan sebagai kejadian luar biasa yang dapat mempengaruhi kinerja pasar seperti: risiko default, restrukturisasi, dan moratorium atas suatu perusahaan. Premium yang dibayarkan dari pihak pembeli kepada pihak penjual disebut dengan "spread" dengan nilai kontrak khusus dan dibayarkan per kuartal. CDS diperdagangkan oleh lembaga finansial seperti investment bank, melalui mekanisme over-the-counter (OTC). Dalam OTC market tersebut, praktik perdagangan yang terjadi adalah para pedagang akan saling mencari counterparty dan ketika masing-masing counterparty sudah bertemu, maka proses selanjutnya adalah menciptakan hubungan kontrak bilateral dengan kesepakatan harga kontrak didasarkan pada proses tawarmenawar antara kedua belah pihak (Badan 
Kemenkeu Fiskal (BKF), Kemenkeu, 2013). CDS termasuk dalam salah satu instrument kredit derivative yang banyak diminati oleh para investor karena sesudah secara langsung berkontribusi dalam krisis global. (Longstaff dan Myers, 2009)

Pembeli (Investor) CDS membayar biaya tertentu (premium) kepada penyedia CDS (Seller) dalam kurun waktu tertentu (maturity) dengan tujuan memberikan perlindungan terhadap aset yang dibeli apabila sewaktu-waktu terjadi "credit event". Perlindungan yang diberikan adalah berupa kompensasi yang dibayarkan oleh penyedia
CDS (Seller). Contoh nya yaitu misal $X$ sebagai pemilik aset rujukan yang diterbitkan $\mathrm{Y}$ mengikat kontrak dengan $\mathrm{Z}$ sebagai penjual CDS. Kontrak mensyaratkan $X$ melakukan pembayaran berkala atau tahunan kepada Z. Apabila tidak terjadi credit event, maka $X$ terus melakukan pembayaran sampai dengan aset rujukan jatuh tempo. Apabila terjadi credit event pada $Y$ seperti default atau kebangkrutan, $X$ menghentikan pembayaran berkala ke $\mathrm{Z}$ dan mendapatkan pembayaran sejumlah nilai pari aset rujukan (Kemenkeu, 2013). Berikut ini grafik dari mekanisme CDS (Gambar 1).

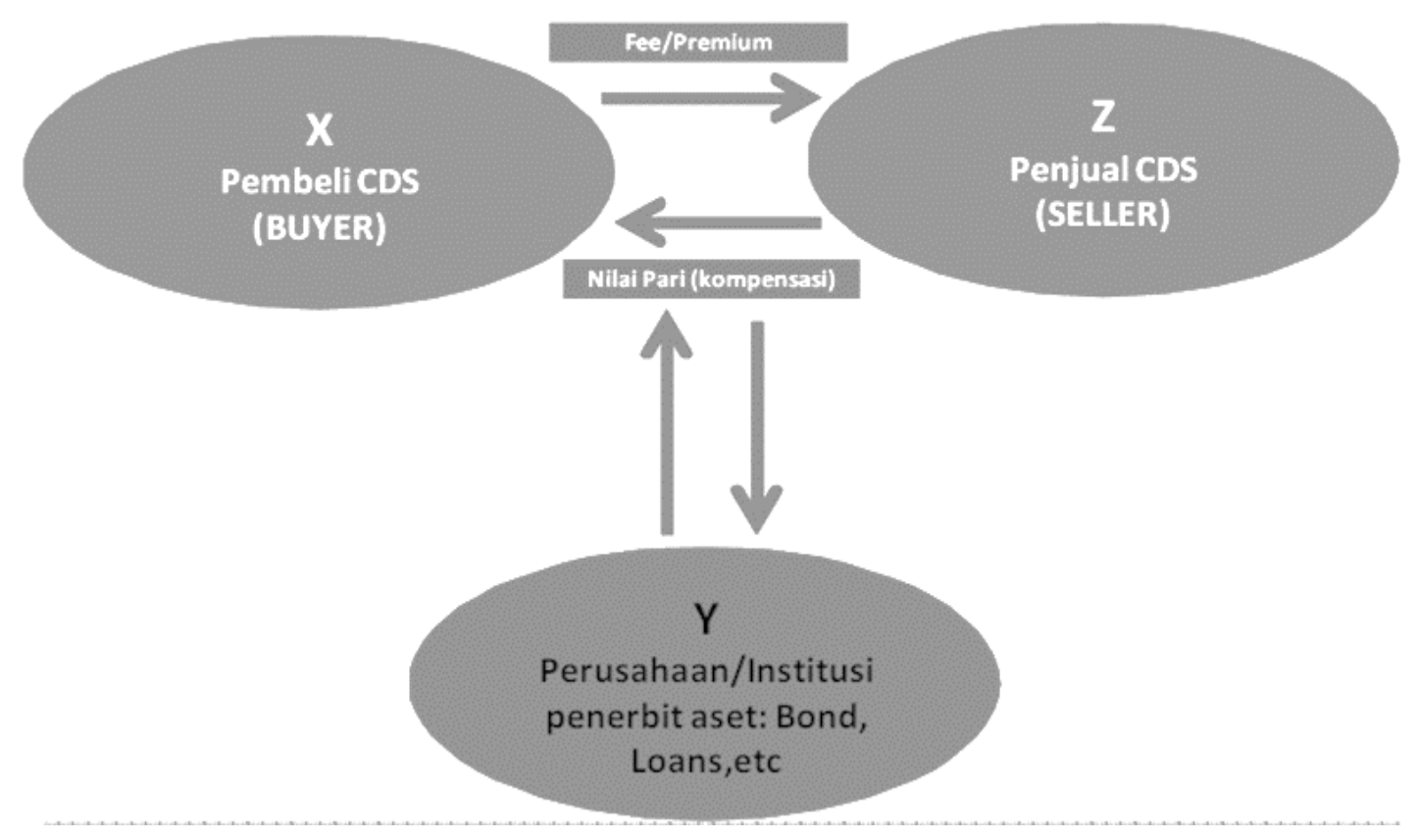

\section{Gambar 1 \\ Mekanisme Credit Default Swap (CDS) di Indonesia \\ Sumber: ISDA, 2013 dalam Badan Kebijakan Fiskal (BKF) Kemenkeu 2013}

Sebagai contoh perbedaan antara penilaian credit ratings dan Credit Default Swap (CDS), Perusahaan keuangan ternama yaitu The Lehman Brother memperoleh nilai credit rating yaitu " $\mathrm{A}$ " dalam kurun waktu tahun 2006-2008 sebelum mengalami kepailitan pada tanggal 20 September 2008. Penjelasan lebih lengkap dapat dilihat pada Tabel 1.

Dapat dilihat pada Tabel 1 bahwa The Lehman Brothers dari penilaian credit ratings menunjukkan kestabilan dengan nilai "A", sedangkan penilaian dari Credit Default Swap (CDS) mengalami fluktuatif yang diawali pada tanggal 2 Januari 2006 sebesar 25 bps, dan diakhiri dengan nilai yang sangat tinggi yaitu pada tanggal 15 September 2008 sebesar 703 bps sebelum dinyatakan pailit. Hal tersebut memperlihatkan penilaian dengan menggunakan instrumen CDS lebih akurat dibandingkan dengan credit ratings dikarenakan penilaian credit ratings yang menunjukkan nilai " $\mathrm{A}$ " 
yang artinya masuk dalam investment grade (perusahaan memiliki kemampuan yang cukup dalam melunasi utangnya) akan tetapi The Lehman Brothers mengalami kepailitan. Sedangkan, jika dilihat dari nilai CDS yang semakin besar sebelum The Lehman Brothers dinyatakan pailit menujukkan bahwa dengan nilai CDS semakin besar, maka potensi risiko default juga semakin besar.

Nilai CDS yang tinggi dapat menunjukkan tingginya risiko gagal bayar atas surat utang (obligasi). Tingginya nilai CDS dapat juga mencerminkan permintaan atas CDS yang semakin tinggi sehingga dapat mengindikasikan bahwa semakin banyak pihak yang berekspektasi surat utang tersebut memiliki potensi lebih besar untuk mengalami gagal bayar (default). Berikut ini perkembangan data CDS Indonesia dari tahun 2008-2017. (Gambar 2).
Tabel 1

Perbandingan Credit Ratings dan CDS The Lehman Brothers

\begin{tabular}{lcc}
\hline \hline \multirow{2}{*}{ Date } & \multicolumn{2}{c}{ Lehman Brothers } \\
\cline { 2 - 3 } & Spread & Rating \\
\hline $2-1-06$ & 25 & $\mathrm{~A}$ \\
$1-1-07$ & 21 & $\mathrm{~A}$ \\
$2-4-07$ & 38 & $\mathrm{~A}$ \\
$10-7-07$ & 45 & $\mathrm{~A}$ \\
$17-8-07$ & 150 & $\mathrm{~A}$ \\
$1-1-08$ & 120 & $\mathrm{~A}$ \\
$14-3-08$ & 448 & $\mathrm{~A}$ \\
$12-9-08$ & 702 & $\mathrm{~A}$ \\
$15-9-08$ & 703 & $\mathrm{~A}$ \\
\hline
\end{tabular}

Sumber: Sand. 2012. "The impact of macro-economic variables on the sovereign CDS of the Eurozone countries".

Dapat dilihat dari Gambar 2 menunjukkan bahwa terjadi fluktuasi nilai dari Credit Default Swap (CDS) Indonesia.



2008200920102011201220132014201520162017

Perkembangan CDS Tenor 10 Tahun

Gambar 2

Perkembangan Credit Default Swap Indonesia Tahun 2008-2017 Sumber: www.katadata.co.id

Tahun 2008 menjadi tahun dengan nilai CDS terbesar dikarenakan pada saat itu terjadi krisis global yang disebabkan beberapa masalah di Amerika Serikat salah satunya Subprime Mortgage. Adanya fluktuasi nilai CDS tersebut menunjukkan terdapat faktor yang menjadi indikator penting mempengaruhi nilai Credit Default Swap (CDS), yaitu dalam penelitian ini penulis ingin melihat dari sisi fundamental ekonomi makro yang terdiri dari inflasi, suku bunga, IHSG serta dari sisi sentimen global yaitu Fed Fund Rate (FFR), Harga minyak, dan indeks Dow Jones. 
Credit Default Swap (CDS) yang merupakan acuan untuk melihat persepsi risiko investasi di Indonesia dan tingkat inflasi pada periode Januari 2008-Desember 2017 mengalami pergerakan secara fluktuatif yang dipengaruhi oleh berbagai faktor baik faktor eksternal maupun internal yang dapat dilihat pada Gambar 3.

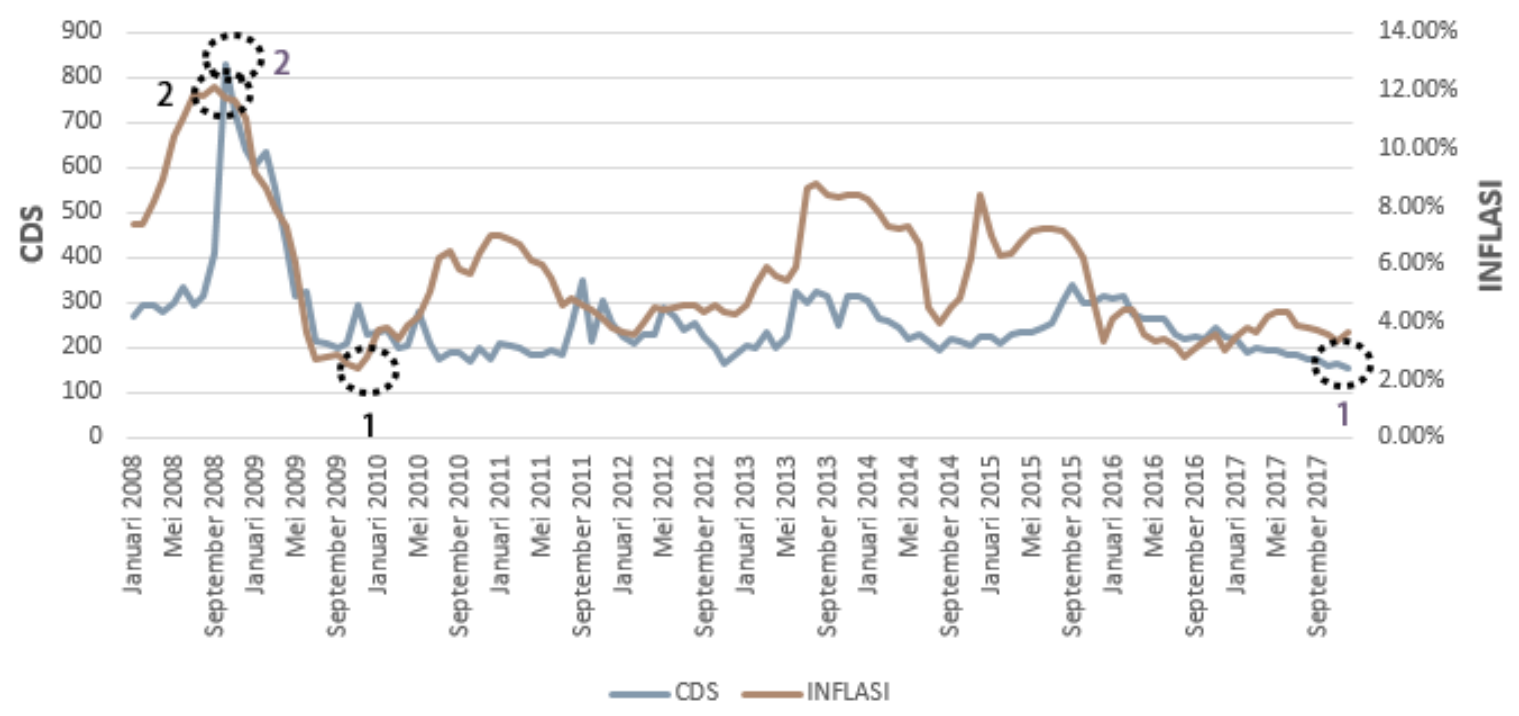

\section{Gambar 3 \\ Pergerakan Credit Default Swap (CDS) dan Tingkat Inflasi Indonesia Periode Januari 2008-Desember 2017}

Sumber: www.katadata.co.id

Gambar 3 menjelaskan bahwa CDS mengalami titik terendah pada Desember 2017 (lingkaran 1 biru), CDS pada bulan tersebut mencapai 155,95. Sedangkan, nilai CDS tertinggi terjadi pada Oktober 2008 (lingkaran 2 biru) mencapai angka 829,9. Hal tersebut terjadi akibat krisis subprime mortage yang terjadi di Amerika Serikat sehingga berdampak dengan persepsi risiko investasi yang tinggi terhadap negara emerging market seperti Indonesia. Selain itu, variabel inflasi juga mengalami pergerakan fluktuatif secara bulanan (month to month). Gambar 3 menjelaskan bahwa inflasi mengalami titik terendah pada November 2009 (lingkaran 1 hitam), inflasi pada bulan tersebut mencapai $2,41 \%$. Sedangkan, tingkat inflasi tertinggi terjadi pada September 2008 (lingkaran 2 hitam) mencapai $12,14 \%$. Dilihat dari grafik pergerakan CDS dan Inflasi tersebut terdapat hubungan yang positif dalam setiap tren per bulannya. Hal tersebut menunjuk- kan bahwa ketika inflasi meningkat maka nilai Indeks CDS Indonesia juga akan meningkat dan sebaliknya.

Variabel Tingkat Suku Bunga mengalami pergerakan fluktuatif secara bulanan (month to month) yang disebabkan oleh berbagai faktor baik dari internal maupun eksternal. Gambar 4 menjelaskan bahwa tingkat suku bunga mengalami titik terrendah pada Desember 2017 (lingkaran 1 hitam), tingkat suku bunga pada bulan tersebut mencapai $4,25 \%$.

Sedangkan, tingkat suku bunga tertinggi terjadi pada Oktober 2008 (lingkaran 2 hitam) mencapai 9,5\%. Dilihat dari grafik pergerakan CDS dan tingkat suku bunga tersebut terdapat hubungan yang positif dalam tren per bulannya. Hal tersebut menunjukkan bahwa ketika tingkat suku bunga meningkat maka nilai Indeks CDS Indonesia juga akan meningkat dan sebaliknya. 


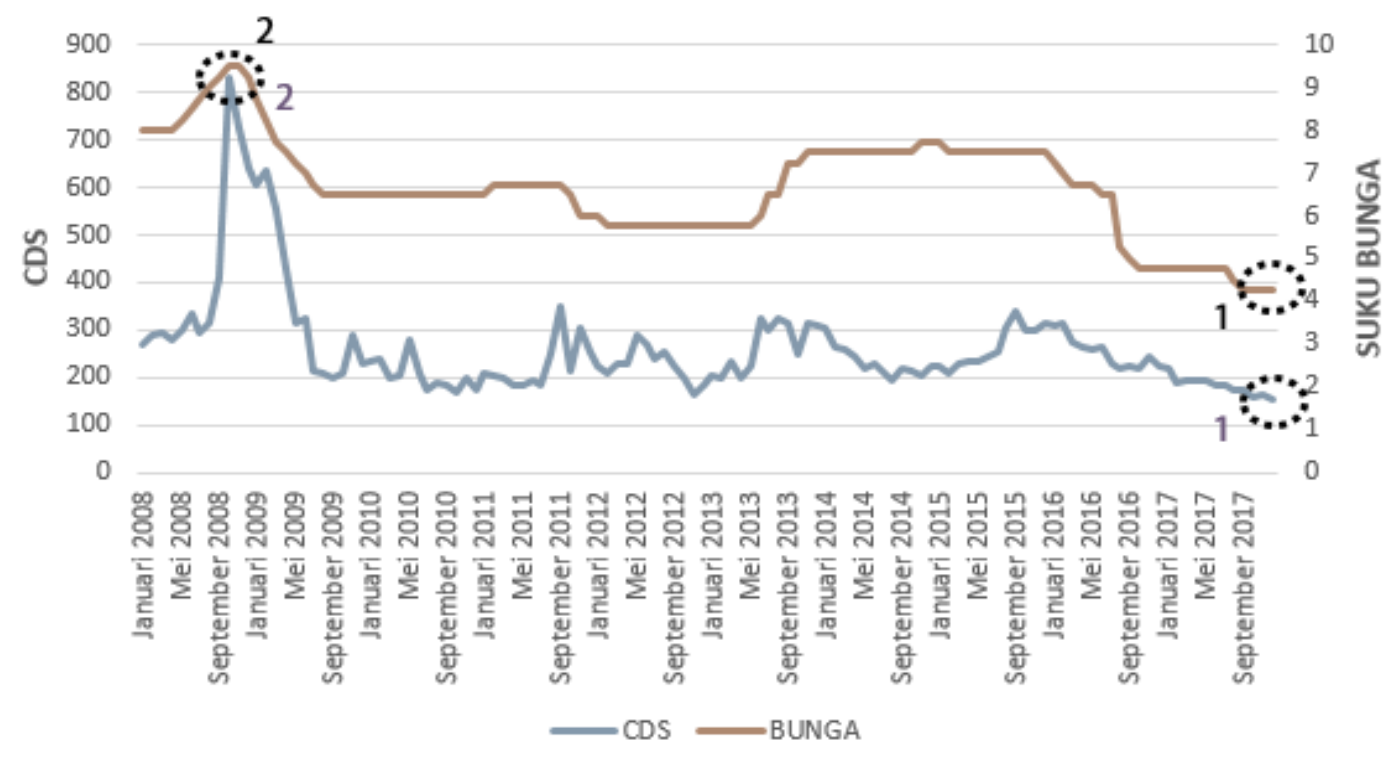

\section{Gambar 4 \\ Pergerakan Credit Default Swap (CDS) dan Tingkat Suku Bunga Indonesia Periode Januari 2008-Desember 2017}

Sumber:www.katadata.co.id

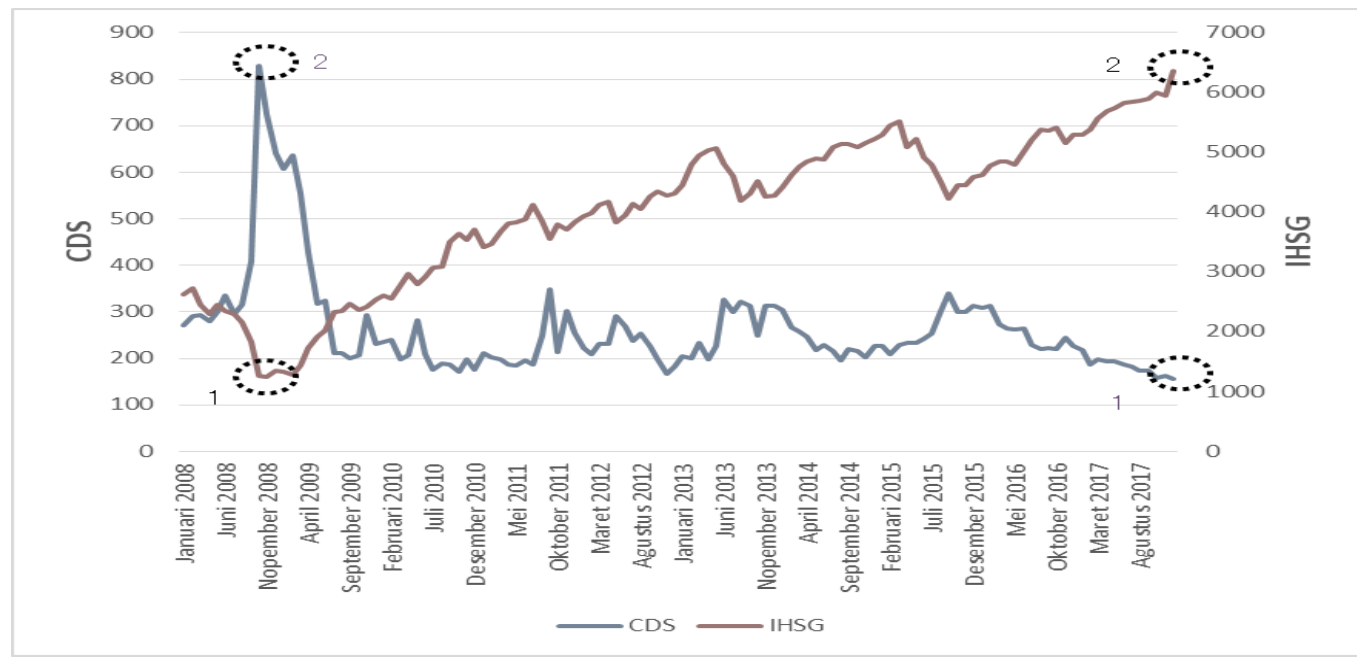

\section{Gambar 5}

Pergerakan Credit Default Swap (CDS) Indonesia dan Indeks Harga Saham Gabungan (IHSG) Periode Januari 2008-Desember 2017

Sumber:www.katadata.co.id dan www.finance.yahoo.com, 2019

Dapat dilihat pada Gambar 5 menunjukkan bahwa IHSG mengalami titik terendah pada November 2008 (lingkaran 1 hitam), IHSG pada bulan tersebut mencapai 1.241,541. Sedangkan, IHSG tertinggi terjadi pada Desember 2017 (lingkaran 2 hitam) mencapai 6.355,654. Dilihat dari grafik pergerakan CDS dan tingkat suku bunga tersebut terdapat hubungan yang negatif atau berbanding terbalik dalam tren per bulannya.

Hal tersebut menunjukkan bahwa ketika IHSG meningkat maka nilai Indeks CDS Indonesia akan turun dan sebaliknya. 


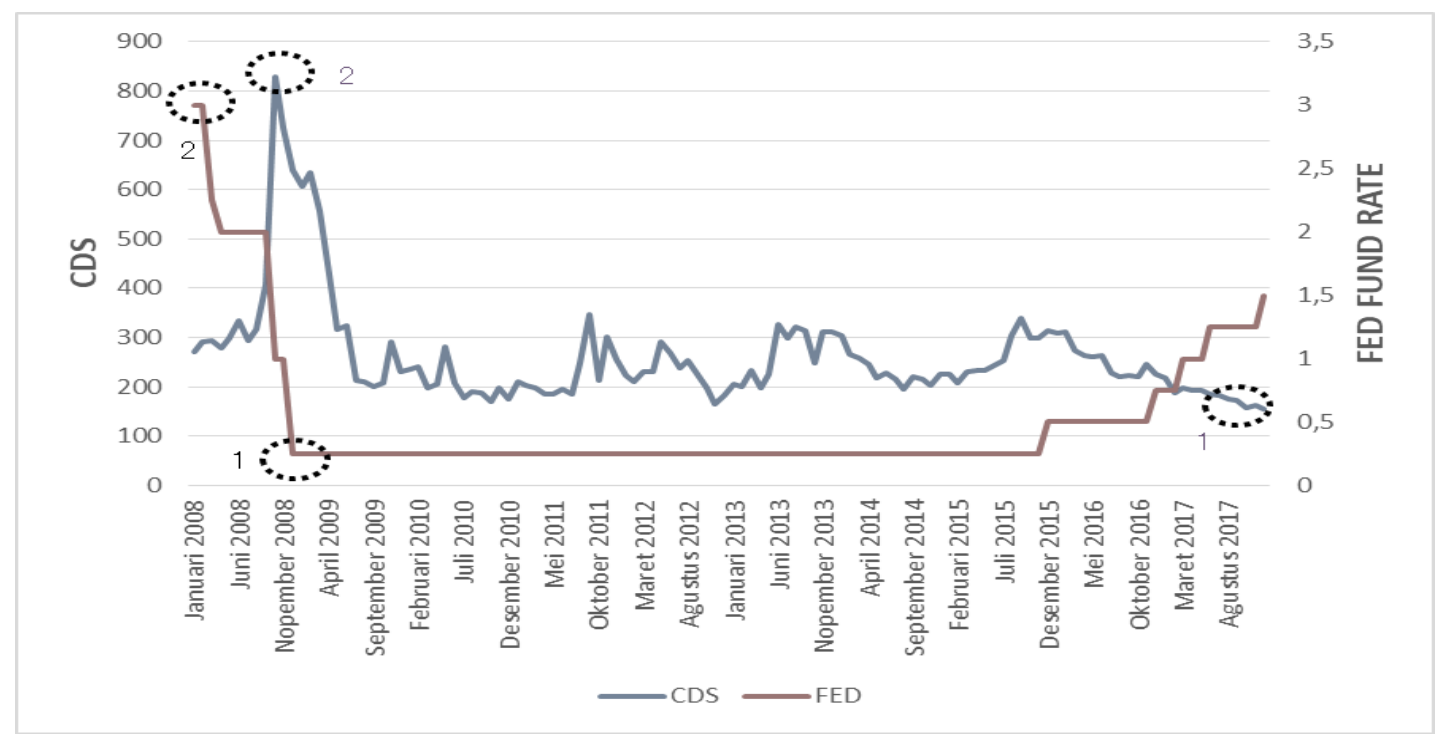

\section{Gambar 6 \\ Pergerakan Credit Default Swap (CDS) Indonesia dan Suku Bunga \\ Sumber:www.katadata.co.id \\ The Fed (Fed Fund Rate) Periode Januari 2008-Desember 2017}

Variabel Tingkat Suku Bunga The Fed (Fed Fund Rate) mengalami pergerakan yang stabil secara bulanan (month to month) yang disebabkan oleh kebijakan the Fed utuk mengatasi berbagai faktor baik dari internal maupun eksternal. Gambar 6 menjelaskan bahwa tingkat suku bunga the Fed mengalami titik terendah pada Desember 2008 sampai dengan November 2015 (lingkaran 1 hitam) yaitu mencapai $0,25 \%$. Hal tersebut merupakan kebijakan the Fed untuk meningkatkan economies of scale Amerika Serikat. Sedangkan, tingkat suku bunga the Fed tertinggi terjadi pada Januari 2008 (lingkaran 2 hitam) mencapai 3\%. Dilihat dari grafik pergerakan CDS dan tingkat suku bunga the Fed tersebut, terdapat hubungan yang negatif dalam tren per bulannya. Hal tersebut menunjukkan bahwa ketika tingkat suku bunga the Fed meningkat maka nilai Indeks CDS Indonesia juga akan turun dan sebaliknya. Variabel Harga Minyak Dunia yang bersumber dari data West Texas Intermediate (WTI) menunjukkan adanya pergerakan yang fluktuatif secara bulanan (month to month) yang disebabkan oleh berbagai faktor baik dari internal maupun eksternal. Gambar 7 menjelaskan bahwa harga minyak dunia mengalami titik terrendah pada Januari 2009 yaitu sebesar 41,68 US\$ per Barel. Sedangkan, harga minyak dunia tertinggi terjadi pada Bulan Mei 2008 (lingkaran 2 hitam) sebesar 127,35 US\$ per Barel. Dilihat dari grafik diatas, terdapat hubungan yang negatif dalam tren per bulannya antara pergerakan CDS dan harga minyak dunia. Hal tersebut menunjukkan bahwa ketika harga minyak dunia meningkat maka nilai Indeks CDS Indonesia akan turun dan sebaliknya.

Variabel tingkat Indeks Industrial Dow Jones (DJIA) menunjukkan adanya pergerakan yang fluktuatif secara bulanan (month to month) yang disebabkan oleh berbagai faktor baik dari internal maupun eksternal. Gambar 8 menjelaskan bahwa Indeks Dow Jones mengalami titik terendah pada Februari 2009 yaitu sebesar 7.062,9. Sedangkan, Indeks Dow Jones tertinggi terjadi pada Bulan Desember 2017 (lingkaran 2 hitam) sebesar $24.719,2$. Dilihat dari grafik diatas, terdapat hubungan yang positif dalam tren per bulannya antara pergerakan CDS dan Indeks Dow Jones. Hal tersebut menunjukkan bahwa ketika Indeks Dow Jones meningkat maka nilai Indeks CDS Indonesia akan naik dan sebaliknya. 


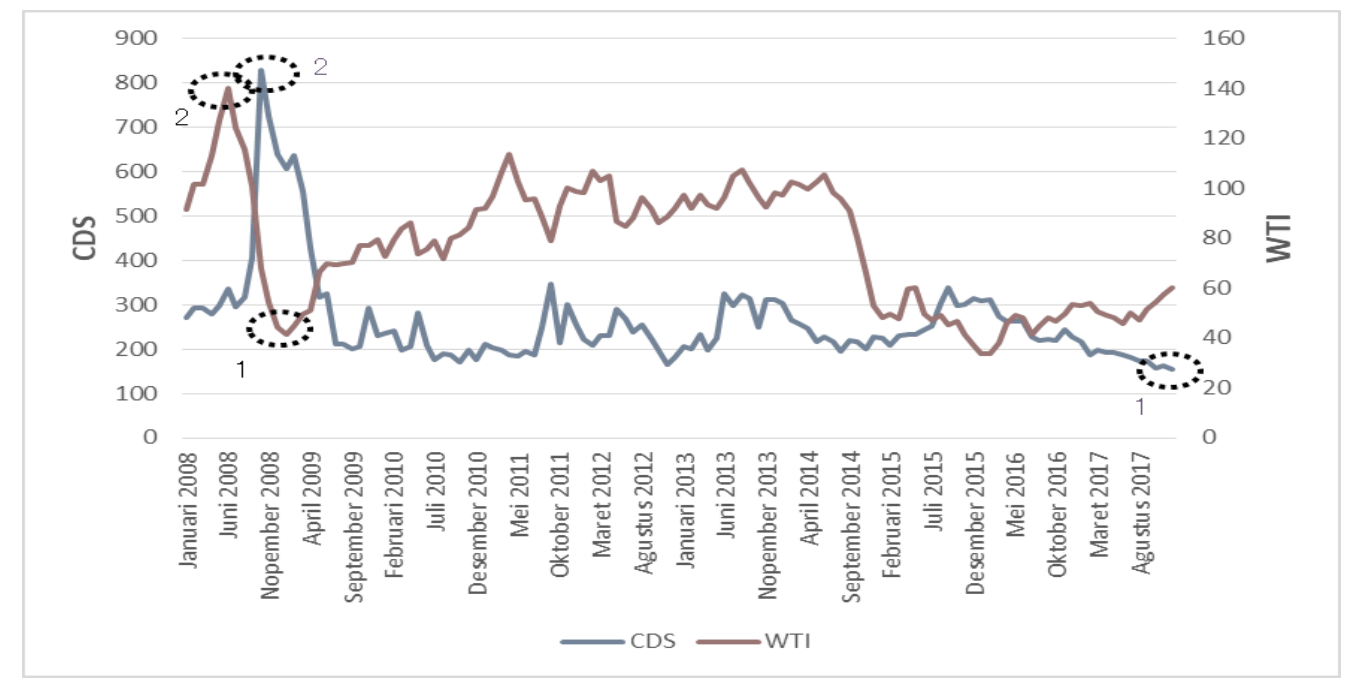

Gambar 7

Pergerakan Credit Default Swap (CDS) Indonesia dan Harga Minyak Dunia (WTI) Periode Januari 2008-Desember 2017

Sumber:www.katadata.co.id

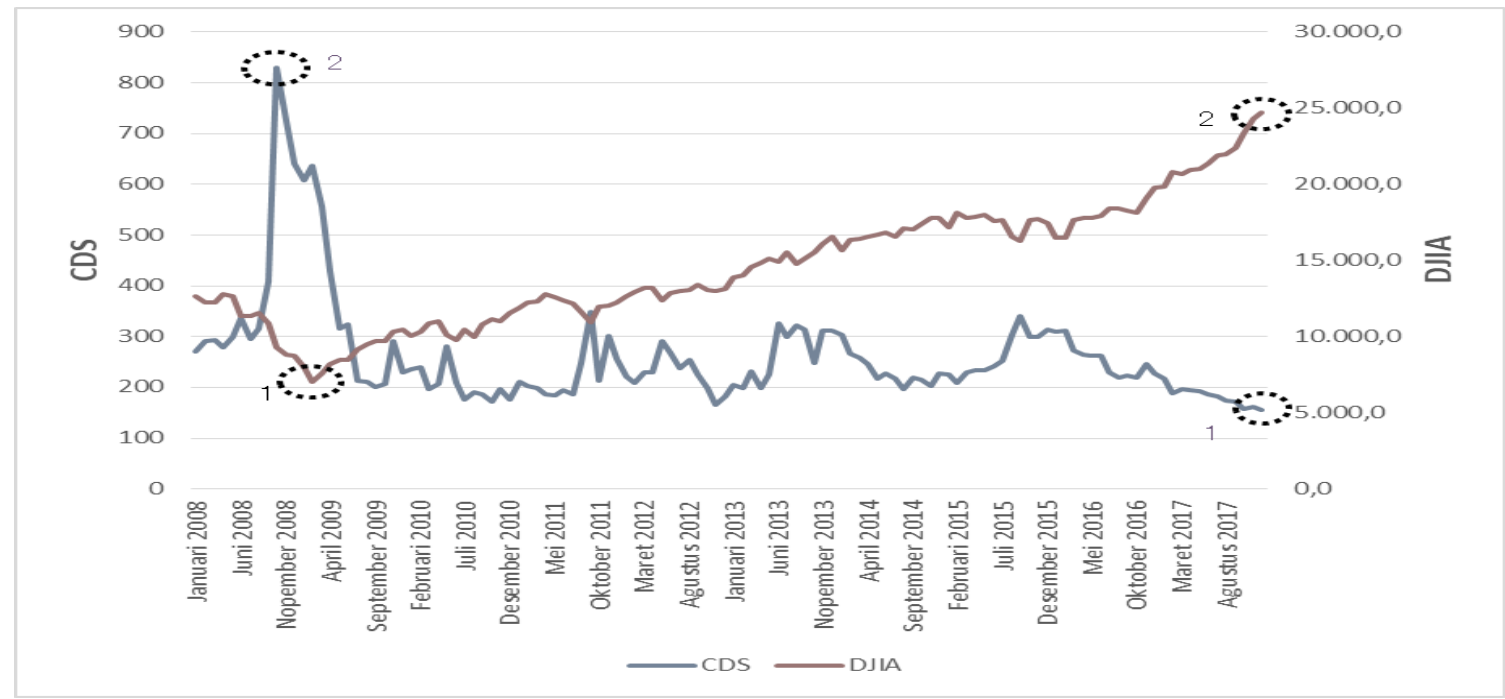

Gambar 7

Pergerakan Credit Default Swap (CDS) Indonesia dan Harga Minyak Dunia (WTI) Periode Januari 2008-Desember 2017

Sumber: www.katadata.co.id

Pada penelitian ini akan mengkaji dan memperbarui hasil penelitian yang telah dilakukan. Penelitian mengenai pengaruh dari sisi fundamental ekonomi makro dan sisi sentimen global terhadap Credit Default Swap (CDS) di Indonesia sampai saat ini masih jarang dilakukan sehingga penelitian ini masih relevan untuk dilakukan. Pene- litian ini ingin melihat persepsi investor terhadap Indonesia yang diukur dari CDS. Variabel fundamental ekonomi makro yang digunakan dalam penelitian ini antara lain adalah tingkat tingkat inflasi, suku bunga (interest rate), dan Indeks Harga Saham Gabungan (IHSG). Variabel sentimen global yang digunakan dalam penelitian ini adalah 
Fed Fund Rate (FFR), Harga Minyak Dunia, dan Dow Jones index.

\section{TINJAUAN TEORETIS}

Inflasi merupakan kecenderungan dari harga-harga umum untuk naik secara terus menerus. Kenaikan harga dari satu atau dua barang saja tidak disebut inflasi, kecuali bila kenaikan tersebut mengakibatkan kenaikan sebagian besar dari harga barang lainnya. Kenaikan harga ini dapat diukur dengan menggunakan indeks harga. Beberapa indeks harga yang sering digunakan untuk mengukur inflasi antara lain: indeks biaya hidup atau Indeks Harga Konsumen (Consumer Price Index), indeks harga perdagangan besar (Wholesale Price Index), dan GNP deflator.

Variabel selanjutnya yaitu tingkat suku bunga yang mana dapat diartikan sebagai harga dari pinjaman. Suku bunga merupakan sejumlah rupiah yang dibayar akibat telah mempergunakan dana sebagai balas jasa. Perubahan suku bunga merupakan perubahan dalam permintaan uang (kredit). Kenaikan suku bunga mengakibatkan penurunan permintaan agregat atau pengeluaran investasi. Sebaliknya, peningkatan suku bunga akan mengakibatkan peningkatan permintaan agregat (Aryaningsih, 2008). Adapun tingkat suku bunga yang digunakan dalam penelitian ini adalah tingkat suku bunga BI rate dan BI 7 Days Reverse Repo Rate (BI 7 DRR).

IHSG dapat digunakan sebagai indikator kinerja bursa saham utama. Karena perhitungannya yang menggunakan harga saham agregat, maka IHSG juga menggambarkan kondisi bursa saham keseluruhan. Tidak hanya itu, IHSG seringkali digunakan sebagai pengukuran dari tingkat pengembalian dan indikator kinerja portofolio (Pradhypta, et al., 2018). Dalam hal ini, IHSG mencerminkan suatu nilai yang berfungsi sebagai pengukuran kinerja suatu saham gabungan di bursa efek (BEI). Maksud gabungan dari seluruh saham ini adalah kinerja saham yang dimasukkan dalam perhitungan seluruh saham yang tercatat di bursa tersebut. Selain dari sisi fundamental makro ekonomi Indonesia yang sudah dijelaskan sebelumnya, terdapat variabel dari sisi sentimen global diantaranya; suku bunga The Fed merupakan tingkat suku bunga yang ditetapkan oleh The Fed selaku otoritas moneter di Amerika Serikat (AS) yang digunakan sebagai patokan bagi suku bunga pinjaman maupun simpanan bagi bank dan atau lembaga-lembaga keuangan di seluruh AS. Ketika Fed Rate naik, maka bunga pinjaman maupun simpanan di bank dan lembaga keuangan lainnya juga bisa naik. Jika bunga simpanan di bank-bank di Amerika naik, maka itu akan menarik minat investor dari seluruh dunia untuk menempatkan dana mereka dalam bentuk tabungan atau deposito di Amerika. Tidak hanya bunga tabungan, ketika Fed Rate naik maka bunga obligasi yang diterbitkan perusahaan-perusahaan di Amerika juga biasanya akan ikut naik. Sehingga, memungkinkan investor memindahkan dananya dari Indonesia kembali ke Amerika Serikat, atau bahkan ke wahana investasi lainnya.

Variabel selanjutnya yaitu harga minyak dunia merupakan harga minyak yang dijual oleh produsen luar negeri yang mana pergerakan harga tersebut sangat mempengaruhi perekonomian Indonesia dikarenakan Indonesia masih memerlukan impor yang digunakan untuk konsumsi rumah tangga dan industri. Saat ini penetapan harga minyak mentah dunia didasarkan pada dua kelompok atau standar yang umum yaitu Brent (Brent Crude) dan WTI (West Texas Intermediate) dimana dalam penelitian ini menggunakan standar harga minyak WTI.

Variabel Indeks Dow Jones Industrial Average (DJIA) merupakan rata-rata indeks saham 30 perusahaan industri yang ada di Amerika Serikat dimana satuannya adalah basis point. Dow Jones Industrial Average (DJIA) merupakan indeks pasar AS tertua yang masih berjalan yang dihitung menggunakan weighted average. Indeks Dow Jones adalah salah satu indeks pasar saham yang didirikan oleh editor The Wall Street 
Journal dan pendiri Dow Jone s dan Company, Charles Dow. (Prakarsa dan Kusuma, 2008).

Terdapat beberapa penelitian tentang faktor yang mempengaruhi nilai Credit Default Swap (CDS) baik dari sisi fundamental ekonomi makro maupun sentimen global. Penelitian dari Mellios dan Paget (2006) menjelaskan bahwa terdapat hubungan positif antara inflasi dan CDS, dimana semakin tinggi tingkat inflasi maka semakin tinggi juga nilai CDS. Hal tersebut menunjukkan ekonomi yang tidak stabil sedangkan jika tingkat inflasi rendah maka menunjukkan kebijakan moneter yang stabil. Diperkuat oleh penelitian dari Tampubolon dan Hidayat (2013), menunjukkan bahwa nilai koefisien variabel inflasi sebesar 13,0 dan memiliki pengaruh positif terhadap credit default swap pada tingkat kepercayaan 95\%. Hal ini berarti jika inflasi di negaranegara ASEAN meningkat $1 \%$ maka akan mendorong terjadinya peningkatan premi Credit Default Swap (CDS) di negara-negara ASEAN sebesar 13,0\%. Selain itu, diperkuat penelitian dari Rashid et al. (2017), Maltriz dan Molchanov (2013). CDS sebagai salah satu kelas aset berisiko akan mengalami penurunan permintaan ketika harga-harga pokok di suatu negara tidak stabil. Hal ini juga sekaligus menunjukkan tingkat integrasi yang ada di pasar derivatif terhadap siklus perekonomian dunia.

Hasil penelitian dari Aini (2012) menunjukkan bahwa suku bunga (interest rate) berpengaruh positif dan signifikan terhadap Credit Default Swap (CDS) dimana jika terjadi peningkatan $1 \%$ pada suku bunga yaitu yield SUN tenor 10 tahun maka akan meningkatkan CDS sebesar 1,445\%. Semakin besar imbal hasil yang dijanjikan pemerintah maka semakin besar pula risiko yang terdapat dalam obligasi tersebut, sehingga, meningkatkan kekhawatiran investor dan berdampak pada peningkatan CDS. Berbeda dengan penelitian dari Aini (2012), Rashid et al. (2017) yang meneliti CDS di Pakistan, menjelaskan bahwa dalam jangka panjang maupun jangka pendek, variabel suku bunga berpengaruh negatif dan signifikan terhadap CDS. Alasannya yaitu dengan tingginya suku bunga maka dapat menjadi acuan dalam melihat kondisi kesehatan ekonomi suatu negara, sehingga investor boleh melakukan permintaan dengan premi CDS yang rendah.

Aini (2012) yang meneliti Credit Default Swap (CDS) di Indonesia menjelaskan bahwa terdapat pengaruh negatif antara stock returns (Imbal hasil IHSG) terhadap CDS di Indonesia. Pengaruh negatif tersebut yaitu dengan peningkatan return IHSG dan diiringi penurunan angka CDS sehingga dapat disimpulkan bahwa pasar modal Indonesia sedang dalam keadaan yang baik sehingga kekhawatiran investor terhadap gagal bayar pemerintah atau risiko default Indonesia menjadi rendah. Hal tersebut akan menyebabkan penurunan angka CDS yang menjadi indikator risiko default Indonesia. Selain dari sisi fundamental ekonomi makro Indonesia, terdapat faktor lain yang dapat mempengaruhi nilai CDS di Indonesia yaitu sentimen global. Menurut hasil penelitian dari Vicente dan Matsumura (2009) yang meneliti terjadinya default di Brazil menunjukkan bahwa Fed Fund Rate menjadi faktor yang dominan dalam menjelaskan kemungkinan terjadinya default di Brazil.

Pratomo dan Puspitasari (2008) melakukan penelitian tentang CDS dan Implikasinya. Hasil dari penelitian ini menunjukkan bahwa credit dan sovereign ratings memainkan peranan penting di pasar keuangan dengan membantu investor untuk memfilter informasi yang penting untuk keputusan berinvestasi. Terkait dengan hal ini, penggunaan CDS sebagai salah satu indikator risiko suatu negara sebaiknya dilakukan secara berhati-hati mengingat rendahnya reliabilitas spread CDS, transparansi pasar CDS, dan likuiditas instrumen ini terutama di emerging economies yang termasuk adalah beberapa setengah anggota ASEAN.

Alexander dan Kaeck (2007) meneliti tentang pengaruh interest rate, stock return, dan implied volatility terhadap CDS spread. Penelitian tersebut dilakukan guna melihat 
pengaruh determinan perubahan indeks iTraxx di Eropa. Hasil penelitian menunjukkan bahwa interest rate, stock return, dan implied volatility berpengaruh signifikan terhadap CDS Spread di Eropa. Pada penelitian ini menekankan bahwa CDS pada perusahaan keuangan tidak bisa disamakan dengan CDS pada perusahan non-keuangan karena CDS pada perusahaan non-keuangan memiliki spread rendah.

Chuffart dan Hooper (2017) yang meneliti harga minyak terhadap Credit Default Swap (CDS) di Rusia dan Venezuela menunjukkan bahwa di Venezuela imbal hasil dari harga minyak dunia (crude oil) berpengaruh negatif dan signifikan terhadap perubahan CDS. Sejumlah kebijakan dapat berdampak pada ekonomi yaitu ketika harga minyak sedang volatile, sebaiknya negara melakukan diversifikasi ekonomi. Beberapa negara dapat mengatur untuk berpindah dari orientasi ekonomi sumber daya alam (natural resource oriented) ke ekonomi terbuka seperti pelayanan finasial di Kota Dubai atau untuk turis (Indonesia). Selain itu, harga minyak yang kolaps dapat menjadi kesempatan pemerintah untuk menurunkan subsidi minyaknya, yang mana selalu mempresentasikan pengeluaran dari anggaran pemerintah. Sehingga, dananya dapat disalurkan ke hal-hal yang bersifat produktif seperti pembangunan infrastruktur.

Baum dan Wan (2010) melakukan penelitian mengenai ketidakpastian makroekonomi dan credit default swap menyebar pada perusahaan individu. Untuk mengukur variabel makroekonomi, digunakan varians variabel antara lain tingkat pertumbuhan PDB, indeks produksi industry, indeks komposit S dan P 500 dan variabel lain seperti nilai pasar, rasio leverage, laba atas ekuitas, dan rasio pembayaran dividen. Hasil menunjukkan bahwa ketidak pastian ekonomi makro merupakan determinan penting dari CDS menyebar. Hasil penelitian dari Fung dan Gregory, (2008) menggunakan Vector Autoregression (VAR) model mengindikasikan bahwa stock market memperlihatkan pengaruh baik investment grade CDS maupun high-yield pasar CDS. Interaksi yang penting dari high-yield perubahan indeks CDS dan imbal hasil stock market mempengaruhi investor untuk lebih berhati-hati terhadap naik turun informasi yang dinamis antara pasar modal Amerika Serikat dan pasar CDS untuk lebih paham terhadap risiko default. Pelaku pasar dianjurkan untuk mengamati dan melihat informasi dalam kedua pasar tersebut untuk tujuan trading dan lindung nilai (Hedging) yang dilihat dari nilai CDS.

Penelitian ini merupakan hasil modifikasi dari beberapa penelitian sebelumnya yang telah dilakukan. Namun variabel yang digunakan dalam penelitian ini tidak hanya berasal dari 1 (satu) penelitian saja. Beberapa penelitian tersebut memilik gap penelitian masing-masing. Penelitian ini akan mengkaji dan memperbarui hasil penelitian yang telah dilakukan. Penelitian mengenai pengaruh dari sisi fundamental ekonomi makro dan sisi sentimen global terhadap Credit Default Swap (CDS) di Indonesia sampai saat ini masih jarang dilakukan sehingga penelitian ini masih relevan untuk dilakukan. Penelitian ini ingin melihat persepsi investor terhadap Indonesia yang diukur dari CDS. Variabel fundamental ekonomi makro yang digunakan dalam penelitian ini antara lain adalah tingkat tingkat inflasi, suku bunga (interest rate), dan Indeks Harga Saham Gabungan (IHSG). Variabel sentimen global yang digunakan dalam penelitian ini adalah Fed Fund Rate (FFR), Harga Minyak Dunia, dan indeks Dow Jones. Adapun Kerangka berpikir dalam penelitian ini adalah sebagai berikut. (Gambar 8).

\section{METODE PENELITIAN}

Pada penelitian ini akan meneliti pengaruh sisi fundamental ekonomi makro dan sentimen global terhadap Credit Default Swap (CDS) di Indonesia dengan menggunakan analisis ECM-EG (Error Correction Model-Eagle Granger). Dalam penelitian ini, variabel dependen (variabel Y) yang digunakan adalah variabel Credit Default Swap (CDS) Indonesia tenor 10 tahun. Variabel 
independen (Variabel X) yang digunakan adalah dari sisi fundamental ekonomi makro diantarannya: variabel tingkat inflasi, tingkat suku bunga, dan Indeks Harga Saham Gabungan (IHSG) Indonesia. Selain itu, dari sisi sentimen global diantaranya: variabel Fed Fund Rate, harga minyak dunia, Dow Jones Index. Saat ini sangat penting memper- tahankan posisi nilai Credit Default Swap (CDS) Indonesia. CDS sendiri selain dapat sebagai lindung nilai (hedging) juga dapat menjadi salah satu indikator untuk menilai risiko investasi suatu negara, sehingga para investor dapat memberikan penilaian sebelum menanamkan modalnya.

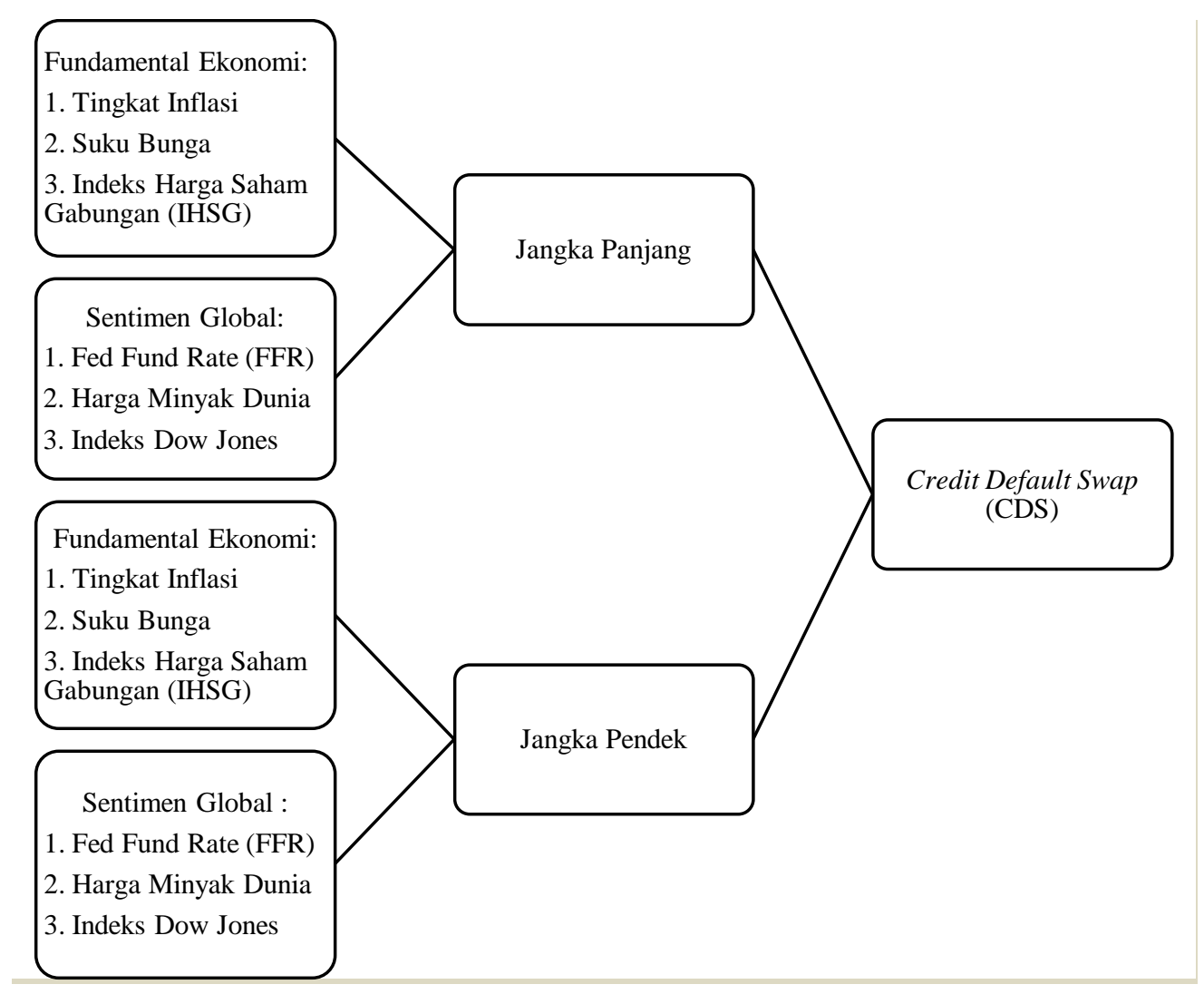

\section{Gambar 8 \\ Rerangka Pemikiran}

Penelitian ini menggunakan jenis penelitian kuantitatif dimana data yang digunakan dalam suatu skala numerik (angka). Data yang digunakan merupakan data time series dengan periode yang digunakan pada penelitian ini adalah Januari 2008-Desember 2017. Jenis data yang dipakai dalam penelitian ini adalah data sekunder yaitu data yang telah dikumpulkan oleh lembaga pengumpul data serta dipublikasikan pada masyarakat pengguna data. Penggunaan data sekunder adalah dengan tujuan efisiensi karena data yang digunakan berasal lebih dari satu variabel. Teknik analisis data diantarannya sebagai berikut:

\section{Uji Akar Unit (Unit Root Test)}

Uji stasioneritas dapat dilakukan dengan unit root-test. Uji ini terkenal dengan sebutan Augmented Dickey-Fuller (ADF) Test. Uji ini digunakan untuk melihat stasioneritas data. Jika suatu data time series tidak stasioner pada tingkat level maka data dapat diuji kembali pada tingkat first difference atau second difference. Hasil uji akar unit jika 
seluruh data sudah stationer pada tingkat level maka dapat dilanjutkan estimasi pada regresi linier biasa. Namun jika hasil tidak stasioner pada tingkat manapun atau semua data dinyatakan tidak stasioner maka estimasi selanjutnya adalah uji kointergasi (Gujarati, 2003).

\section{Uji Derajat Integrasi}

Uji Intergrasi dilakukan untuk mengetahui pada data keberapa data tersebut stasioner dengan melihat derajat diferensiasinya. Insukindro (1992) mengatakan bahwa uji derajat integrasi dapat dilakukan dengan penaksiran model autoregressif sebagai berikut:

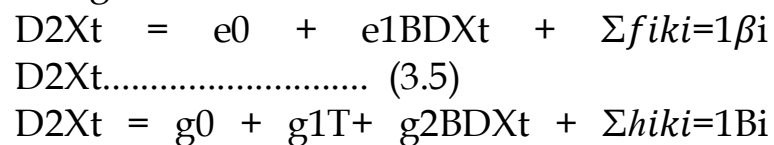

D2Xt. (3.6)

Dengan:

$\mathrm{D} 2 \mathrm{Xt}=\mathrm{DXt}-\mathrm{DXt}-1$

$\mathrm{BDXt}=\mathrm{DXt}-1$

Untuk melihat pada derajat berapa data penelitian ini stasioner, maka perlu diuji menggunakan nilai statistic DF dan ADF dari nisbah $t$ pada koefisien regresi BDXt. Apabila nilai e0 dan g0 sama dengan nol, variabel $\mathrm{Xt}$ belum stasioner di deferensiasi pertama. Jika belum stasioner perlu diuji derajat integrasi lagi sampai nilai variabel $\mathrm{Xt}$ sudah stasioner. Sedangkan, apabila e1 dan g1 bernilai sama dengan satu, maka variabel $\mathrm{Xt}$ sudah stasioner pada diferensiasi pertama. Variabel stasioner apabila nilai hitung mutlak DF dan ADF lebih besar (>) dari nilai kritis mutlak (ketika $\alpha=5 \%$ ).

\section{Uji Kointegrasi (Cointegration Test)}

Uji kointegrasi menurut Gujarati (2003) adalah uji ada tidaknya hubungan jangka panjang antara variabel bebas dan variabel terikat. Uji ini merupakan kelanjutan dari uji stationary. Tujuan utama uji kointegrasi ini adalah untuk mengetahui apakah residual terkointegrasi stationary atau tidak. Apabila variabel terkointegrasi maka terdapat hubungan yang stabil dalam jangka panjang.
Sebaliknya jika tidak terdapat kointegrasi antar variabel maka implikasi tidak adanya keterkaitan hubungan dalam jangka panjang. Istilah kointegrasi dikenal juga dengan istilah error, karena deviasi terhadap ekuilibrium jangka panjang dikoreksi secara bertahap melalui series parsial penyesuaian jangka pendek. Apabila data sudah stasioner dapat dihasilkan estimasi Error Correction Model (ECM). Uji kointegrasi pada penelitian ini memiliki dua hipotesis, yaitu:

$\mathrm{H}_{0}=$ tidak ada hubungan kointegrasi antar variabel

$\mathrm{H}_{1}=$ ada hubungan kointegrasi antar variabel.

Penelitian ini menggunakan uji kointegrasi dengan trace statistic, karena dengan melihat nilai trace statistic dapat mengetahui ada atau tidaknya kointegrasi dalam model tersebut. Apabila nilai kritis trace lebih kecil dari trace statistic maka kedua variabel tersebut terdapat kointegrasi atau tidak dapat membentuk model dinamis jangka pendek atau diestimasi secara ECM, dan sebaliknya apabila nilai kritis trace lebih besar dari trace statistic maka kedua variabel tersebut tidak terdapat kointegrasi atau dapat membentuk model dinamis jangka pendek atau diestimasi secara ECM (Gujarati, 2003).

\section{Hasil Uji Statistik}

Dari hasil regresi akan dilakukan uji statistik yang meliputi uji t (uji tiap variabel), uji $F$ (secara bersama-sama) dan uji $R^{2}$ (koefisien determinasi).

a. Uji R 2

Koefisien determinasi $\left(R^{2}\right)$ memiliki tujuan untuk melihat seberapa jauh variasi variabel bebas dapat menerangkan dengan baik variasi variabel terikat. Nilai $\mathrm{R}^{2}$ yang sempurna adalah satu, yaitu apabila keseluruhan variasi dependen dapat dijelaskan sepenuhnya oleh variabel bebas yang dimasukkan ke dalam model terikat (Gujarati, 2003).

b. Uji $t$

Uji statistik $t$ pada dasarnya menunjukkan seberapa jauh pengaruh satu variabel independen secara individual dalam 
menerangkan variasi variabel dependen (Gujarati, 2003).

c. Uji $\mathrm{F}$

Uji F pada dasarnya dimaksudkan untuk membuktikan secara statistik bahwa seluruh variabel bebas berpengaruh secara bersama-sama terhadap variabel terikat.

\section{Model Koreksi Kesalahan (Error Corection Model)}

Teori Engle dan Granger menyebutkan bahwa jika dua variabel $\mathrm{Y}$ dan $\mathrm{X}$ terkointegrasi, maka hubungan diantara keduanya dapat diekspresikan dalam ECM. Penggunaan kointegrasi EG didasarkan atas uji ADF dan statistik regresi kointegrasi CRDW (Cointegration Regression Durbin Watson). Dasar pengujian ADF adalah statistic Dickey-Fuller, sedangkan uji CDRW didasarkan atas nilai Durbin Watson Ratio, dan keputusan penerimaan atau penolakannya didasarkan atas angka statistik CDRW (Gujarati, 2003)

Dinamika jangka pendek dijelaskan dengan mekanisme koreksi kesalahan. Sedangkan apabila mekanisme koreksi kesalahan merupakan model yang sahih, maka variabel-variabel yang digunakan merupakan himpunan variabel yang berkointegrasi, sebaliknya bila variabel-variabel yang digunakan tidak berkointegrasi, maka residual dari ECM tidak stasioner dan spesifikasi model tidak sahih. Uji kointegrasi bertujuan untuk menguji stasioneritas residual regresi kointegrasi. Pengujian ini penting dalam penggunaan model dinamik ECM, karena jika residual regresi kointegrasi stasioner maka residual dapat membentuk model jangka pendek ECM yang telah dikembangkan oleh Engle Granger.

Langkah berikutnya adalah mencari nilai residu yang disebut dengan Error Correction Term (ECT). Kemudian dilakukan uji kointegrasi untuk menguji apakah residual dari ECT stasioner atau tidak (Granger dan Engle, 1978 dalam Prasetiono 2010). Keterkaitan uji kointegrasi dengan ECM ditelusuri melalui uji statistik ECT yang signifikan secara statistik. Sebaliknya apabila koefisien ECT tidak signifikan, maka spesifikasi model yang digunakan tidak valid (Insukindro, 1992). Pada ECM Engle Granger (ECM EG), apabila koefisien ECT (-a. Signifikan dan bernilai negatif, maka spesifikasi model yang digunakan adalah shahih atau valid, sedangkan untuk ECM baku, spesifikasi model valid jika nilai koefisien ECT (1) adalah positif dan signifikan.

\section{ANALISIS DAN PEMBAHASAN}

Penelitian kuantitatif ini melihat pengaruh jangka panjang dan jangka pendek faktor fundamental ekonomi makro Indonesia dan sentimen global terhadap nilai Credit DefaultSwap (CDS) Indonesia pada Periode Januari 2008 hingga Desember 2017. Teknik analisis yang digunakan adalah analisis regresi Error Correction Model (ECM). Data yang diperoleh diolah dengan bantuan program eviews 9. Hasil penelitian dapat dilihat sebagai berikut:

1. Uji akar-akar unit dan uji derajat integrasi

Uji akar-akar unit (unit roots test) merupakan salah satu uji yang diperlukan pada data time series untuk melihat ketidak stasioneran data agar tidak menyebabkan regresi lancung pada penelitian Insukindro (1992). Sedangkan uji derajat integrasi merupakan kelanjutan dari uji akar-akar unit, uji ini dilakukan apabila variabel tidak stasioner pada tingkat level karena uji ini dilakukan untuk melihat pada tingkat diferensi keberapa semua variabel stasioner.

Tabel 2

Uji Akar Unit

\begin{tabular}{lcccc}
\hline \multirow{2}{*}{ Variabel } & \multicolumn{4}{c}{ Unit Root } \\
\cline { 2 - 5 } & \multicolumn{2}{c}{ Level } & \multicolumn{2}{c}{ 1 $^{\text {st }}$ Difference } \\
\cline { 2 - 5 } & ADF & Prob & ADF & Prob \\
\hline LNCDS & -3.0449 & 0.1247 & -12.167 & $0.0000^{* * *}$ \\
\hline INF & -2.8274 & 0.1906 & -6.9896 & $0.000^{* * *}$ \\
\hline SB & -2.2758 & 0.4434 & -4.1787 & $0.0065^{* * *}$ \\
\hline LNIHSG & -1.9553 & 0.6191 & -8.0423 & $0.0000^{* * *}$ \\
\hline FED & -4.1004 & $0.0083^{* * *}$ & -11.3036 & $0.0000^{* * *}$ \\
\hline LNWTI & -1.7666 & 0.7148 & -7.4856 & $0.0000^{* * *}$ \\
\hline LNDJIA & -3.7006 & $0.0261^{* *}$ & -10.418 & $0.0000^{* * *}$ \\
\hline
\end{tabular}


Keterangan:

$$
\begin{aligned}
& * \quad: \text { signifikan pada } \alpha=0.10 \\
& * * \text { signifikan pada } \alpha=0.05 \\
& * * \text { : signifikan pada } \alpha=0.01
\end{aligned}
$$

Tabel 2 menjelaskan bahwa variabel suku bunga the Fed dan Indeks Dow Jones stasioner pada tingkat level pada tingkat signifikansi 5\%. Karena tidak semua variabel stasioner pada level maka selanjutnya perlu dilakukan uji derajat integrasi. Dapat dilihat dari Tabel 3 bahwa semua variabel baik variabel terikat maupun variabel bebas stasioner pada 1st difference. Hal ini dapat dilihat dari nilai probabilitas unit root semua variabel kurang dari tingkat signifikansi 1\% atau nilai ADF semua variabel kurang dari nilai ADF kritis pada signifikansi 5\%.

\section{Uji Kointegrasi}

Konsep kointegrasi pada dasarnya adalah untuk mengetahui kemungkinan adanya hubungan keseimbangan jangka panjang pada variabel-variabel yang diobservasi. Dalam konsep kointegrasi, dua atau lebih variabel runtun waktu tidak stasioner akan terkointegrasi bila kombinasinya juga linier sejalan dengan berjalannya waktu, meskipun bisa terjadi masing-masing variabelnya bersifat tidak stasioner. Bila variabel runtun waktu tersebut terkointegrasi maka terdapat hubungan yangstabil dalam jangka panjang (Gujarati, 2003).

Tabel 3

Uji akar-akar unit residual pada tingkat level

\begin{tabular}{ccc}
\hline \hline \multirow{2}{*}{ Variabel } & \multicolumn{2}{c}{ Uji Kointegrasi } \\
\cline { 2 - 3 } & \multicolumn{2}{c}{ Level } \\
\cline { 2 - 3 } & ADF & Prob \\
\hline E & -5.0003 & $0.0004^{* * *}$ \\
\hline
\end{tabular}

Untuk membuktikan adanya kointegrasi dalam model maka perlu dilakukan pengujian DF untuk menguji residual (E) yang didapatkan dari hasil regresi. Jika nilai residual (E) signifikan pada alfa 5\% maka dalam model terdapat kointegrasi. Hasil pengujian DF model dalam penelitian ini dapat dilihat pada Tabel 4. Hasil uji akarakar unit nilai residual (E) pada Tabel 4 menjelaskan bahwa residual dari persamaan penelitian ini stasioner pada level dengan tingkat kesalahan 5\%. Oleh karena itu, variabel $\mathrm{E}$ dapat digunakan dalam model jangka pendek ECM-EG.

\section{Hasil Uji Statistik}

a. Uji R 2

Koefisien determinasi $\left(\mathrm{R}^{2}\right)$ memiliki tujuan untuk melihat seberapa jauh variasi variabel bebas dapat menerangkan dengan baik variasi variabel terikat.

Tabel 4

Uji R ${ }^{2}$

\begin{tabular}{ccc}
\hline \hline Uji R & Jangka & Jangka \\
Pendek & Panjang \\
\hline R-squared & 0.609748 & 0.703052 \\
\hline $\begin{array}{c}\text { Adjusted R- } \\
\text { squared }\end{array}$ & 0.588841 & 0.687285 \\
\hline
\end{tabular}

Tabel 4 menjelaskan bahwa dalam jangka pendek, variasi variabel-variabel bebas dalam menjelaskan variasi variabel terikat berada di nilai tengah yaitu $50 \%$ lebih sedikit. Variasi variabel bebas dalam menjelaskan variasi variabel terikat sebesar $58,9 \%$, sisanya $41,1 \%$ dipengaruhi oleh variasi variabel lain diluar model.

Nilai koefisien determinasi $\left(\mathrm{R}^{2}\right)$ jangka panjang yang terlihat pada Tabel 4 menjelaskan bahwa kemampuan variabelvariabel bebas kuat dalam menjelaskan variasi variabel terikat karena nilai koefisien determinasinya mendekati 1 . Variasi variabel bebas dalam menjelaskan variasi variabel terikat sebesar $68,7 \%$, sisanya $31,3 \%$ dipengaruhi oleh variasi variabel lain diluar model.

Besarnya koefisien determinasi dalam jangka panjang dibanding jangka pendek mengindikasikan bahwa dalam jangka panjang, variabel bebas dapat lebih menjelaskan variasi variabel terikat (nilai Indeks CDS). 
b. Uji t

Uji statistik $\mathrm{t}$ pada dasarnya menunjukkan seberapa jauh pengaruh satu variabel independen secara individual dalam menerangkan variasi variabel dependen (Gujarati, 2003). Hasil Uji T-Statistik adalah sebagai berikut:

\section{Tabel 5}

Hasil Uji T-Statistik

\begin{tabular}{lcc}
\hline \hline \multirow{2}{*}{$\begin{array}{c}\text { Variabel } \\
\text { Bebas }\end{array}$} & \multicolumn{2}{c}{ Jangka Pendek } \\
\cline { 2 - 3 } t- hitung & t- tabel \\
\hline D(INF) & 0.339777 & 1.65776 \\
D(SB) & 0.206282 & 1.65776 \\
D(IHSG) & 7.383598 & 1.65776 \\
D(FED) & 0.549296 & 1.65776 \\
D(WTI) & 0.891918 & 1.65776 \\
D(DJIA) & 2.660490 & 1.65776 \\
ECT & 4.642168 & 1.65776 \\
INF & 3.270622 & 1.65776 \\
SB & 1.773389 & 1.65776 \\
LNIHSG & -4.567171 & 1.65776 \\
FED & -2.933162 & 1.65776 \\
LNWTI & -2.925217 & 1.65776 \\
LN DJIA & 2.385872 & 1.65776 \\
\hline
\end{tabular}

Hasil uji t-statistik yang dapat dilihat pada Tabel 5 menjelaskan bahwa dalam jangka pendek untuk hanya variabel IHSG dan Indeks Dow Jones yang berpengaruh signifikan (t-hitung $>\mathrm{t}$-tabel) terhadap nilai Indeks Credit Default Swap (CDS), sedangkan dalam jangka panjang hanya variabel suku bunga yang tidak signifikan (t-hitung < t-tabel), sementara 5 variabel bebas lainnya signifikan terhadap nilai Indeks CDS.

\section{c. Uji F}

Uji F pada dasarnya dimaksudkan untuk membuktikan secara statistik bahwa seluruh variabel bebas berpengaruh secara bersama-sama terhadap variabel terikat.

Tabel 6 Uji F-statistik

\begin{tabular}{ll}
\hline \hline & Uji F \\
\hline F-statistic & 44.58969 \\
Prob(F-statistic) & 0.000000 \\
\hline
\end{tabular}

Tabel 6 menjelaskan bahwa uji F statistik persamaan pengaruh fundamental ekonomi makro dan sentimen global terhadap nilai Indeks CDS menunjukkan hasil signifikan jika dilihat pada alfa 5\%. Hal ini berarti secara bersama-sama variabel bebas diantaranya inflasi, suku bunga, IHSG, suku bunga the Fed, harga minyak dunia dan Indeks Dow Jones berpengaruh signifikan terhadap variabel terikat yaitu Indeks CDS.

\section{Model Koreksi Kesalahan (Error Corection Model)}

Hasil estimasi ECM jangka pendek persamaan fundamental ekonomi makro dan sentimen global terhadap nilai Indeks Credit Default Swap (CDS) akan dijelaskan lebih rinci pada Tabel 7.

Koefisien residual (ECT) yakni sebesar 0,262356 dan signifikan pada derajat kepercayaan 5\%, maka sesuai dengan teori ECT yakni bernilai negatif dan signifikan, maka dapat dikatakan spesifikasi model yang digunakan dalam penelitian ini adalah valid dan ECM-EG telah lolos dari seluruh uji asumsi klasik. Nilai koefisien residual (ECT) menunjukkan bahwa variabel dependen menyesuaikan variabel independen dengan satu lag atau dengan kata lain hanya sekitar $0,26 \%$ dari ketidaksesuaian antara jangka panjang dan jangka pendek yang dapat dikoreksi.

Dari hasil estimasi regresi ECM jangka pendek maka dapat dilihat bahwa:

a. Inflasi memiliki koefisien positif dan signifikan terhadap nilai Indeks Credit Default Swap (CDS) dalam jangka pendek. Apabila inflasi naik 1 persen maka akan meningkatkan nilai Indeks CDS sebesar 0,004811 .

b. Suku bunga memiliki koefisien negatif terhadap nilai Indeks Credit Default Swap (CDS) dalam jangka pendek. Apabila suku bunga naik 1 persen maka akan menurunkan nilai Indeks CDS sebesar 0,010272 . 
Tabel 7

Hasil Estimasi ECM Jangka Pendek Pengaruh Fundamental Ekonomi Makro dan Sentimen Global terhadap CDS

\begin{tabular}{lccc}
\hline \hline \multicolumn{1}{c}{ Variabel Bebas } & Arah Pengaruh & Koefisien Regresi & Probabilitas \\
\hline D(INF) & + & 0.004811 & 0.7347 \\
D(SB) & - & -0.010272 & 0.8369 \\
D(IHSG) & - & -1.448909 & 0.0000 \\
D(FED) & + & 0.039933 & 0.5839 \\
D(WTI) & - & -0.097306 & 0.3743 \\
D(DJIA $)$ & - & -0.509487 & 0.0089 \\
ECT & - & -0.262356 & 0.0000 \\
R-Squared & & & 0.609748 \\
Adjusted R-squared & & & 0.588841 \\
\hline
\end{tabular}

c. Indeks Harga Saham Gabungan (IHSG) memiliki koefisien negatif terhadap nilai Indeks Credit Default Swap (CDS) dalam jangka pendek. Apabila IHSG naik 1 poin maka akan menurunkan nilai Indeks CDS sebesar 1,448909.

d. Suku Bunga the Fed (Fed Fund Rate) memiliki koefisien positif terhadap nilai Indeks Credit Default Swap (CDS) dalam jangka pendek. Apabila suku bunga the Fed naik 1 persen maka akan meningkatkan nilai Indeks CDS sebesar 0,039933.

e. Harga Minyak Dunia memiliki koefisien negatif terhadap nilai Indeks Credit DefaultSwap (CDS) dalam jangka pendek.
Apabila harga minyak dunia naik 1 US\$ per barel maka akan menurunkan nilai Indeks CDS sebesar 0,097306.

f. Indeks Dow Jones (DJIA) memiliki koefisien negatif terhadap nilai Indeks Credit DefaultSwap (CDS) dalam jangka pendek. Apabila Indeks Dow Jones naik 1 poin maka akan menurunkan nilai Indeks CDS sebesar 0,509487.

Hasil estimasi ECM jangka panjang persamaan fundamental ekonomi makro dan sentimen global terhadap nilai Indeks Credit Default Swap (CDS) akan dijelaskan lebih rinci sebagai berikut:

Tabel 8

Hasil Estimasi ECM Jangka Panjang Pengaruh Fundamental Ekonomi Makro dan Sentimen Global terhadap CDS

\begin{tabular}{cccc}
\hline \hline Variabel Bebas & Arah Pengaruh & Koefisien Regresi & Probabilitas \\
\hline C & + & 0.004811 & 0.7347 \\
INF & + & -0.010272 & 0.8369 \\
SB & + & -1.448909 & 0.0000 \\
LNIHSG & - & 0.039933 & 0.5839 \\
FED & - & -0.097306 & 0.3743 \\
LNWTI & - & -0.509487 & 0.0089 \\
LNDJIA & + & -0.262356 & 0.0000 \\
R-Squared & & & 0.609748 \\
Adjusted R-squared & & & 0.588841 \\
\hline
\end{tabular}

Dari hasil estimasi regresi ECM jangka panjang maka dapat dilihat bahwa:

a. Inflasi memiliki koefisien positif dan signifikan terhadap nilai Indeks Credit Default Swap (CDS) dalam jangka pan- jang. Apabila inflasi naik 1 persen maka akan meningkatkan nilai Indeks CDS sebesar 0,039921.

b. Suku bunga memiliki koefisien positif terhadap nilai Indeks Credit Default 
Swap (CDS) dalam jangka panjang. Apabila suku bunga naik 1 persen maka akan meningkatkan nilai Indeks CDS sebesar 0,041269.

c. Indeks Harga Saham Gabungan (IHSG) memiliki koefisien negatif terhadap nilai Indeks Credit Default Swap (CDS) dalam jangka panjang. Apabila IHSG naik 1 poin maka akan menurunkan nilai Indeks CDS sebesar 0,735261 .

d. Suku Bunga the Fed (Fed Fund Rate) memiliki koefisien negatif terhadap nilai Indeks Credit Default Swap (CDS) dalam jangka panjang. Apabila suku bunga the Fed naik 1 persen maka akan menurunkan nilai Indeks CDS sebesar 0,113406.

e. Harga Minyak Dunia memiliki koefisien negatif terhadap nilai Indeks Credit Default Swap (CDS). Apabila harga minyak dunia naik $1 \%$ maka akan menurunkan nilai Indeks CDS sebesar 0,192416 .

f. Indeks Dow Jones (DJIA) memiliki koefisien positif terhadap nilai Indeks Credit Default Swap (CDS). Apabila Indeks Dow Jones naik 1 poin maka akan meningkatkan nilai Indeks CDS sebesar 0,515802 .

Hasil estimasi menggunakan Error Corection Model-Engle Granger (ECM-EG) menjelaskan bahwa dari variabel sisi fundamental ekonomi makro, dalam jangka pendek Inflasi berpengaruh positif tapi tidak signifikan terhadap nilai Indeks CDS, sedangkan dalam jangka panjang inflasi berpengaruh positif signifikan terhadap nilai Indeks CDS. Inflasi yang meningkat mengakibatkan investasi pada surat utang negara asing cenderung lebih menarik dan menguntungkan sehingga investor cenderung memilih untuk berinvestasi pada surat utang negara asing untuk mendapatkan return yang lebih besar (Listiawati dan Paramita, 2018). Hasil penelitian tersebut sesuai dengan penelitian yang dilakukan oleh Mellios dan Paget (2006) menjelaskan bahwa terdapat hubungan positif antara inflasi dan CDS, dimana semakin tinggi tingkat inflasi maka semakin tinggi juga nilai CDS. Hal tersebut menunjukkan ekonomi yang tidak stabil sedangkan jika tingkat inflasi rendah maka menunjukkan kebijakan moneter yang stabil

Suku bunga dalam jangka pendek meskipun suku bunga berpengaruh tidak signifikan akan tetapi hubungannya sesuai dengan penelitian dari Rashid et al. (2017) yang menjelaskan bahwa dalam jangka panjang maupun jangka pendek variabel suku bunga berpengaruh negatif terhadap CDS. Alasannya yaitu dengan tingginya suku bunga maka dapat menjadi acuan dalam melihat kondisi kesehatan ekonomi suatu negara, sehingga investor boleh melakukan permintaan dengan premi CDS yang rendah.

Efek dalam jangka panjang, jika semakin besar imbal hasil yang dijanjikan pemerintah melalui suku bunga maka semakin besar pula risiko yang terdapat dalam obligasi tersebut, sehingga meningkatkan kekhawatiran investor dan berdampak pada peningkatan CDS. Selain itu, dengan kenaikan suku bunga acuan BI dapat mendorong peningkatan CDS Indonesia di masa-masa mendatang. Sebab, salah satu dampak negatif kenaikan suku bunga acuan adalah potensi melambatnya pertumbuhan ekonomi nasional. Apabila pertumbuhan ekonomi stagnan, ada potensi iklim investasi di Indonesia kurang menarik di kalangan investor asing. Hal inilah yang nantinya dapat menaikkan persepsi risiko investasi di Indonesia.

Variabel Indeks Harga Saham Gabungan (IHSG) baik dalam jangka pendek maupun jangka panjang berpengaruh negatif dan signifikan terhadap nilai Indeks CDS. Hasil studi ini sesuai dengan penelitian dari Aini (2012) yang meneliti Credit Default Swap (CDS) di Indonesia menjelaskan bahwa terdapat pengaruh negatif antara stock returns (Imbal hasil IHSG) terhadap CDS di Indonesia. Pengaruh negatif tersebut yaitu dengan peningkatan return IHSG dan diiringi penurunan angka CDS sehingga dapat disimpulkan bahwa baik dalam jangka 
pendek maupun jangka panjang, pasar modal Indonesia sedang dalam keadaan yang baik sehingga kekhawatiran investor terhadap gagal bayar pemerintah atau risiko default Indonesia menjadi rendah. Hal tersebut akan menyebabkan penurunan angka CDS yang menjadi indikator risiko default Indonesia.

Variabel dari sisi sentimen global, suku bunga the Fed (Fed Fund Rate) dalam jangka pendek, ketika the Fed meningkatkan tingkat suku bunga acuan (Fed Fund Rate) maka para investor akan lebih tertarik untuk mengembalikan modalnya ke Amerika Serikat daripada tetap menyimpan di negara emerging market seperti Indonesia. Hal tersebut artinya dapat meningkatkan persepsi risiko investasi Indonesia yang dapat dilihat dari nilai Indeks CDS. Sedangkan dalam jangka panjang adanya pengaruh negatif, artinya meskipun dalam jangka pendek ketika the Fed menaikkan suku bunga dapat meningkatkan persepsi risiko dikarenakan kembalinya modal investor asing ke Amerika Serikat, tapi jika fundamental ekonomi yang kuat dan adanya kebijakan pemerintah yang dapat menarik bagi investor maka secara jangka panjang dapat menurunkan tingkat persepsi risiko Indonesia. Hal tersebut sesuai dengan penelitian Alexander dan Kaeck (2007) yang meneliti tentang pengaruh interest rate terhadap CDS spread. Penelitian tersebut dilakukan guna melihat pengaruh determinan perubahan indeks iTraxx di Eropa. Hasil penelitian menunjukkan bahwa interest rate volatility berpengaruh signifikan terhadap CDS Spread di Eropa.

Variabel harga minyak dunia dalam jangka pendek, para investor tidak melihat perubahan harga minyak yang meningkat sebagai acuan untuk memberikan persepsi negatif untuk berinvestasi di suatu negara termasuk Indonesia. Banyak faktor yang lebih penting dalam menilai risiko sebelum berinvestasi ke suatu negara. Contohnya dalam penelitian ini yaitu IHSG dan Indeks Dow Jones yang memiliki pengaruh signifikan terhadap Indeks CDS dalam jangka pendek. Selain itu, dalam jangka panjang terdapat pengaruh negatif dan signifikan harga minyak dunia terhadap Indeks CDS. Hasil studi ini sesuai dengan penelitian dari Chuffart dan Hooper (2017) yang meneliti harga minyak terhadap Credit Default Swap (CDS) di Rusia dan Venezuela. Hasil penelitian menunjukkan bahwa di Venezuela imbal hasil dari harga minyak dunia (crude oil) berpengaruh negatif dan signifikan terhadap perubahan CDS. Sejumlah kebijakan dapat berdampak pada ekonomi yaitu ketika harga minyak sedang volatile, sebaiknya negara melakukan diversifikasi ekonomi. Beberapa negara dapat mengatur untuk berpindah dari orientasi ekonomi sumber daya alam (natural resource oriented) ke ekonomi terbuka seperti pelayanan finansial di Kota Dubai atau untuk turis (Indonesia).

Variabel indeks Dow Jones dalam jangka pendek, ketika terjadi kenaikan Indeks Dow Jones di pasar Amerika Serikat tidak membuat para investor mengembalikan modalnya untuk berinvestasi di Amerika Serikat dikarenakan Indeks Dow Jones hanya menjadi indeks bagi perusahaan industrial sedangkan dalam penilaian CDS mencakup keseluruhan aktivitas ekonomi dalam suatu negara.

Pada jangka panjang terdapat pengaruh yang positif terhadap Indeks CDS, hal tersebut menjelaskan bahwa dengan semakin meningkatnya Indeks Dow Jones untuk jangka panjang maka dapat meningkatkan Indeks CDS Indonesia karena jika Indeks Dow Jones meningkat terusmenerus menandakan semakin kuatnya ekonomi di Amerika Serikat dan menjadikan tempat yang lebih menarik untuk berinvestasi dibandingkan tetap menyimpan dananya di negara emerging market termasuk Indonesia. Hasil penelitian ini sesuai dengan penelitian dari Fung dan Sierra (2008) menggunakan Vector Autoregression (VAR) model mengindikasikan bahwa stock market memperlihatkan pengaruh baik investment grade CDS maupun high-yield pasar CDS.

Interaksi yang penting dari high-yield perubahan indeks CDS dan imbal hasil stock 
market mempengaruhi investor untuk lebih berhati-hati terhadap naik turun informasi yang dinamis antara pasar modal Amerika Serikat dan pasar CDS untuk lebih paham terhadap risiko default. Pelaku pasar dianjurkan untuk mengamati dan melihat informasi dalam kedua pasar tersebut untuk tujuan trading dan lindung nilai (Hedging) yang dilihat dari nilai CDS.

\section{SIMPULAN DAN SARAN Simpulan}

Dari hasil estimasi regresi ECM jangka panjang, maka dapat dilihat bahwa inflasi memiliki koefisien positif dan signifikan terhadap nilai Indeks Credit Default Swap (CDS) dalam jangka panjang. Suku bunga memiliki koefisien positif terhadap nilai Indeks Credit Default Swap (CDS) dalam jangka panjang. Indeks Harga Saham Gabungan (IHSG) memiliki koefisien negatif terhadap nilai Indeks Credit Default Swap (CDS) dalam jangka panjang. Suku Bunga the Fed (Fed Fund Rate) memiliki koefisien negatif terhadap nilai Indeks Credit Default Swap (CDS) dalam jangka panjang. Harga Minyak Dunia memiliki koefisien negatif terhadap nilai Indeks Credit Default Swap (CDS). Indeks Dow Jones (DJIA) memiliki koefisien positif terhadap nilai Indeks Credit Default Swap (CDS).

\section{Saran}

Berdasarkan hasil penelitian maka penulis memberikan saran antara lain adalah Bank Indonesia diharapkan dapat menekan dan menjaga laju stabilitas suku bunga dan inflasi. Untuk pemerintah diharapkan dapat meningkatkan cadangan devisa yang akan menimbulkan dampak global karena tingkat suku bunga The Fed, harga minyak dunia dan indeks saham dapat mempengaruhi tingkat perekonomian melalui CDS. Selain itu, pemerintah diharapkan dapat membuat kebijakan mengenai CDS sebagai indicator sovereign risk dalam melihat perkembangan perekonomian negara. Sehingga akan tercipta iklim investasi yang baik sehingga pemerintah dapat menyusun draft kebijakan yang harus diambil guna menurunkan nilai CDS Indonesia.

Penelitian ini masih memiliki keterbatasan antara lain yaitu hanya menggunakan variabel ekonomi makro. Untuk peneliti selanjutnya diharapkan dapat meneliti perkembangan CDS dengan variabel yang lebih luas lagi. Selain itu pada penelitian ini menggunakan data time series, sehingga hanya meneliti pada tahun acuan. Diharapkan peneliti selanjutnya dapat selalu memperbaharui tahun penelitian.

\section{DAFTAR PUSTAKA}

Alexander, C. and Kaeck, A. 2007. Regime Dependent Determinants of Credit Defaukt Swap Spreads. Journal of Bangking dan Finance 32: 1008-1021.

Aini, D. N. 2012. Analisis Interest Rate, Stock Returns, dan Implied Volatility Terhadap Credit Default Swap (CDS) di Indonesia [SKRIPSI]. Universitas Indonesia. Jakarta.

Aryaningsih, N. N. 2008. Pengaruh Suku Bunga, Inflasi dan Jumlah Penghasilan Terhadap Permintaan Kredit di PT BPD Cabang Pembantu Kediri. Jurnal Penelitian dan Pengembangan Sains dan Humaniora. JPPSH (1): 59

Baum, C. F. and Wan, C. 2010. Macroeconomic Uncertainty and Credit Default Swap Spreads. Applied Financial Economics Taylor dan Francis Journal vol 25(15): 1163-1171.

Badan Kebijakan Fiskal (BKF) Kemenkeu, 2013. Credit Default Swap Indonesia: Faktor-faktor yang Mempengaruhi dan Perbandingan dengan Peers. https:// www.kemenkeu.go.id/sites/default/fil es/kajian\%20cds\%20indonesia.pdf.

Diakses pada tanggal 05 Januari 2019

Chuffart, T. dan Hooper, E. 2017. An investigation of oil prices impact on sovereign credit default swaps in Russia and Venezuela. Energy Economics Journal 80: 904-916

Diantimala, Y. 2008. Pengaruh Akuntansi Konservatif, Ukuran Perusahaan, Dan Default Risk Terhadap Koefisien Respon 
Laba (ERC). Jurnal Telaah dan Riset Akuntansi 1(1): 102-122.

Fung, Hung-Gay. and Gregory, S. 2008. Are the U.S. Stock Market and Credit Default Swap Market Related? The Journal of Alternative Investments 11(1): 1-34.

Gujarati, Damodar N. 2003. "Basic Econometrics". New York: McGraw-Hill .

Insukindro. 1992. Pembentukan Model Dalam Penelitian Ekonomi. Jurnal Ekonomi dan Bisnis Indonesia 7(1): 1-18.

Ismailescu, I dan Kazemi, H. 2010. The Reaction of Emerging Market Credit Default Swap Spreads to Sovereign Credit Rating Changes. Jornal of International Bangking dan Finance 34: 28612873

Karlson, E. dan Willebrand, N. 2009. Examining The Determinants of Credit Default Swap Spreads. Journal of European Financial Institution Stockholm University

Listiawati, L.Nurul. dan Paramita, V. S.. 2018. Pengaruh Tingkat Suku Bunga, Inflasi, Debt to Equity Ratio, dan Ukuran Perusahaan terhadap Yield Obligasi pada Perusahaan yang Terdaftar di Bursa Efek Indonesia Tahun 2010-2016. Jurnal Manajemen 15(1): 33-51.

Longstaff, F.A. and Myers, B. 2009. An Analysis of CDO Equity. Journal of Economic 29: 119-135.

Maltriz, D. and Molchanov, A. 2013. Analyzing determinants of bond yield spreads with Bayesian Model Averaging. Journal of Banking dan Finance 37(12): 5275-5284.

Mellios, C. and Paget-Blanc, E. 2006. Which factors determine sovereign credit ratings? European Journal of Finance 12(4): 361-377.

Pradhypta, I. C, Iskandar, D., dan Tarumingkeng, R. C. 2018. Analisis Faktor Faktor Yang Mempengaruhi Indeks Harga Saham Gabungan Di Bursa Efek Indonesia. Jurnal Manajemen Bisnis 13(1).
Prakarsa dan Kusuma. 2008. Analisis Pengaruh Tingkat Suku Bunga SBI, Kurs Tengah BI, Tingkat Inflasi, dan Indeks Dow Jones di New York Stock Exchange dalam Memprediksi Indeks Harga Saham Gabungan di Bursa Efek Jakarta. Jurnal Ekonomi: 305-318.

Prasetiono, D.W. 2010. Analisis Pengaruh Faktor Fundamental Ekonomi Makro dan Harga Minyak terhadap Saham Lq45 dalam Jangka Pendek dan Jangka Panjang. Journal of Indonesian Applied Economics 4(1): 11-25.

Pratomo, W. dan Puspitasari, R. 2008. CDS dan Sejumlah Implikasinya. Jurnal Bank Indonesia: Perkembangan Ekonomi dan Keuangan dan Kerjasama InternasionalTriwulan IV 2008

Rashid, A., Ahmad, F. dan Yasmin, A. 2017. Exploring the relationship between macroeconomic indicators and sovereign credit default swap in Pakistan. The Journal of Risk Finance 8 (4): 368-380.

Sand. 2012. "The impact of macro-economic variables on the sovereign CDS of the Eurozone countries [THESIS]. Groningen: University of Groningen.

Sugema, I. 2012. Krisis Keuangan Global 2008-2009 dan Implikasinya pada Perekonomian Indonesia. Jurmal Ilmu Pertanian Indonesia (JIPI) 17(3): 145-152.

Tampubolon, I.K., dan Hidayat, P. 2013. Analisis Sovereign Risk Di NegaraNegara ASEAN. Jurnal Ekonomi dan Keuangan 1(12): 1-14.

Vicente, J. V. M. and Matsumura, M. S. 2009. The role of macroeconomic variables in sovereign risk. Journal of Emerging Markets Review 11: 229-249.

Credit Default Swap dan Imbal Hasil Obligasi Negara Tenor 10 Tahun, https:/ / databoks.katadata.co.id/datap ublish/2018/09/07/persepsi-riskioinvestasi-cds-indonesia-2018meningkattapi-tidak-setinggi-2008. Diakses pada tanggal 05 Januari 2019 